\title{
N-cadherin promotes epithelial-mesenchymal transition and cancer stem cell-like traits via ErbB signaling in prostate cancer cells
}

\author{
MIN WANG $^{1 *}$, DONG REN ${ }^{1 *}$, WEI GUO ${ }^{1}$, SHUAI HUANG $^{1}$, ZEYU WANG $^{1}$, \\ QIJI LI ${ }^{1}$, HONG DU ${ }^{2}$, LIBING SONG ${ }^{3}$ and XINSHENG PENG ${ }^{1}$ \\ ${ }^{1}$ Department of Orthopaedic Surgery, The First Affiliated Hospital of Sun Yat-sen University, Guangzhou, \\ Guangdong 510080; ${ }^{2}$ Department of Pathology, The First People's Hospital of Guangzhou City, Guangzhou, \\ Guangdong 510180; ${ }^{3}$ State Key Laboratory of Oncology in Southern China/Department of Experimental Research, \\ Sun Yat-sen University Cancer Center, Guangzhou, Guangdong 510060, P.R. China
}

Received October 14, 2015; Accepted November 18, 2015

DOI: 10.3892/ijo.2015.3270

\begin{abstract}
N-cadherin has been reported to be upregulated and associated with metastasis and poor prognosis in prostate cancer patients, however the underlying mechanism still remains puzzling. In the present study, we found that upregulation of $\mathrm{N}$-cadherin enhanced, while downregulation of N-cadherin impaired the invasion, migration, and epithelial to mesenchymal transition (EMT) of prostate cancer (PCa) cells. Overexpression of $\mathrm{N}$-cadherin increased the efficiency of colony and tumor spheroid formation and the stemness factor expression (including c-Myc, K1f4, Sox 2 and Oct4), and vice versa. Furthermore, microarray analysis and western blot analysis mechanistically proved that $\mathrm{N}$-cadherin activated ErbB signaling pathway by upregulating the expression of Grb2, pShc and pERK1/2. Importantly, the regulation of $\mathrm{N}$-cadherin on EMT and stemness was counteracted by lapatinib, a specific ErbB signaling pathway inhibitor. Collectively, these findings demonstrate that $\mathrm{N}$-cadherin regulates EMT and stemness of PCa cells via activating ErbB signaling pathway, which indicates the pivotal role of $\mathrm{N}$-cadherin/ErbB axis in the metastasis of prostate cancer.
\end{abstract}

Correspondence to: Professor Xinsheng Peng, Department of Orthopaedic Surgery, The First Affiliated Hospital of Sun Yat-sen University, 58 Zhongshan 2nd Road, Guangzhou, Guangdong 510080, P.R. China

E-mail: pengxs66@yahoo.com

*Contributed equally

Abbreviations: PCa, prostate cancer; miRNAs, microRNAs; EMT, epithelial-mesenchymal transition; CSCs, cancer stem cells; mCRPC, metastatic castration-resistant prostate cancer

Key words: N-cadherin, prostate cancer, epithelial-mesenchymal transition, cancer stem cell-like properties, ErbB signaling

\section{Introduction}

Prostate cancer (PCa) is the second most frequently diagnosed cancer and bone metastasis is the principal issue, accounting for as many as $90 \%$ of patients with advanced PCa (1). The main therapeutic option for bone metastasis in hormoneresponsive $\mathrm{PCa}$ is androgen deprivation therapy. Despite initial response rates of $80-90 \%$, virtually all treated patients progress to androgen-insensitive disease, a state referred to as metastatic castration-resistant PCa (mCRPC). Although these agents effectively palliate symptoms and prolong life, mCRPC remains incurable $(2,3)$. Therefore, an increased understanding of the mechanisms of PCa bone metastasis and metastatic castration-resistance is needed to develop novel therapeutic approaches.

Epithelial to mesenchymal transition (EMT), as a transient phenomenon involving in the process of metastasis of cancers, plays a key role in tumor cells invasion and metastasis (4). Cancer stem cells (CSCs) are a rare subpopulation of cells with stem cell-like properties which have been found in solid malignancies (5-7), and also are thought to be responsible for cancer relapse and metastasis $(8,9)$. Recent evidence has showed that EMT can generate cancer cells with stemness properties (10). The study of Ribeiro and Paredes revealed that P-cadherin expression, which has been already identified as a breast cancer stem cell marker and invasive promoter, was probably able to identify an intermediate EMT state associated with a metastatic phenotype (11). This important finding implies a direct link between EMT and properties of CSCs. Therefore, unveiling the molecular mechanisms responsible for EMT and CSCs would be helpful to develop new promising therapies for PCa patients (12).

$\mathrm{N}$-cadherin, as a marker of ongoing EMT, is not expressed in normal epithelial cells, but its expression has been demonstrated in several types of carcinomas (13-15). Recent study showed that FGFR signaling was responsible for the initiation of N-cadherin-driven EMT and stemness properties in breast cancer cells (16). In PCa, simultaneous upregulation of $\mathrm{N}$-cadherin and downregulation of E-cadherin have been 
found in more aggressive $\mathrm{PCa}$ lines, primary and metastatic PCa. Importantly, aberrant $\mathrm{N}$-cadherin expression has been reported as crucial in PCa progression not only to metastasis, but also to castration resistance $(13,17)$. Furthermore, in xenografts of castration-resistant $\mathrm{PCa}$, a monoclonal antibody that targeted the ectodomain of $\mathrm{N}$-cadherin inhibited androgenindependent growth, local invasion and metastasis. However, the underlying mechanism of $\mathrm{N}$-cadherin in promoting PCa progression is not fully understood. As a switch from E-cadherin to N-cadherin plays a critical role in EMT and progression of $\mathrm{PCa}$ and high mortality (18), we hypothesize that $\mathrm{N}$-cadherin positively regulates metastatic abilities of $\mathrm{PCa}$ cells by modulating EMT and stemness properties of $\mathrm{PCa}$ cells.

The ErbB family tyrosine kinases consists of four members, ErbB1-4, and ErbB1 and ErbB2 also known as EGFR and HER2, respectively. EGFR was the first receptor evidenced with a relationship between receptor overexpression and epidermoid carcinoma (19). Amplification and mutation of EGFR has been proved to be associated with poor prognosis in cancers, such as glioma (20-22), lung cancer (23-26) and breast cancer $(27,28)$. HER 2 has been also reported to be amplified and been widely studied in breast cancer. HER 2 serves as an important prognosis maker and therapy target for breast cancer (29-31). Furthermore, it has been reported that HER2 could induce EMT in both mammary epithelial cells (32) and breast cancer cells $(33,34)$. Furthermore, activation of ERRB2 and ERRB3 was able to mediate glioblastoma cancer stem-like cell resistance to EGFR-targeted inhibition (35) and activation of EGFR was reported to promote acquisition of stem cell-like properties in head and neck squamous cell carcinoma (36). Currently, the underlying mechanism between ErbB signaling and EMT and stemness of cancer cells is poorly understood, and the role of ErbB signaling in PCa is largely unknown.

In the present study, we reported that $\mathrm{N}$-cadherin positively regulated invasion, migration, EMT and stemness properties of PCa cells. Importantly, through microarray analysis and further test, we found that overexpression of $\mathrm{N}$-cadherin activated ErbB signaling, but not FGF signaling. Furthermore, our results demonstrated that $\mathrm{N}$-cadherin regulated EMT and stem cell-like property linked with ErbB signaling in PCa cells. Taken together, $\mathrm{N}$-cadherin might serve as a novel potential therapeutic target in $\mathrm{PCa}$.

\section{Materials and methods}

Cells and cell culture. The brain metastatic cell line DU145 and the bone metastatic PCa cell line PC-3 were purchased from the American Type Culture Collection (ATCC) and grown in DMEM culture medium (Hyclone) and Ham's F-12 culture medium (Hyclone) respectively, supplemented with $10 \%$ fetal bovine serum (Hyclone). Cells were grown at a humidified atmosphere of $5 \% \mathrm{CO}_{2}$ at $37^{\circ} \mathrm{C}$. Labatinib was purchased and prepared as a $10 \mathrm{mM}$ concentrated stock solution in dimethyl sulphoxide (Fisher Scientific).

Vectors and retroviral infection. N-cadherin gene was amplified from cDNA by RT-PCR and cloned into the pMSCV-EF2 lentiviral vector. Two human $\mathrm{N}$-cadherin-targeting shRNA sequences were cloned into pSuper-retro-puro to generate
pSuper-retro-N-cadherin RNAi (s) and the sequences of RNAi\#1 and RNAi\#2 are GCTGAAAGAACTGAAGCATTT and AAATGCTTAGTTCTTTCAGC, respectively. Retroviral production and infection were performed as previously described (37). Stable cell lines expressing N-cadherin or $\mathrm{N}$-cadherin shRNAs were selected for 10 days with $0.5 \mathrm{mg} / \mathrm{ml}$ puromycin.

Microarray analysis. Total RNA from PC-3/vector, PC-3/Ncadherin-RNAi and N-cadherin-overexpression were extracted. Total RNA from each sample was quantified by the NanoDrop ND-1000 and RNA integrity was assessed by standard denaturing agarose gel electrophoresis (38). Microarray analysis was performed commercially by the Shanghai Biochip Corp. according to standard Agilent protocol. Briefly, integrity and concentration of RNA was assessed after RNA extraction and prior to sample labeling. Total RNA of each sample was used for labeling and array hybridization with the following steps: i) reverse transcription with Invitrogen Superscript ds-cDNA synthesis kit; ii) ds-cDNA labeling with NimbleGen one-color DNA labeling kit; iii) array hybridization using the NimbleGen Hybridization system and followed by washing with the NimbleGen wash buffer kit; iv) array scanning using the Axon GenePix 4000B microarray scanner (Molecular Devices Corp.). Data were extracted and normalized using NimbleScan v2.5 software. Results are provided in the NimbleScan Generated Data Folder. Further data analysis was performed using Agilent GeneSpring GX v11.5.1 software. Bioinformatics analysis and visualization of microarray data were performed with the $\mathrm{MeV}$ v4.4 program (http://www. tm4.org/mev/) (39).

Quantitative reverse transcription-PCR. The procedure was performed according to the instrcution of All-in-One ${ }^{\mathrm{TM}}$ miRNA qRT-PCR Detection kit (GeneCopoeia, USA), as described previously (40). The relative expression levels from three independent experiments were counted following the $2^{-\Delta \Delta \mathrm{Ct}}$ method of Livak and Schmittgen (41). The qRT-PCR primers for N-cadherin, c-Myc, OCT-4, SOX2, Klf4 and glyceraldehyde-3-phosphate dehydrogenase (GAPDH) were designed by the Primer Express version 2.0 software (Applied Biosystems). N-cadherin forward, 5'-GGCATACACCATG CCATCTT-3'; reverse, 5'-GTGCATGAAGGACAGCCTCT-3'; c-Myc forward, 5'-CACCGA GTCGTAGTCGAGGT-3'; reverse, 5'-GCTGCTTAGACGCTGGATTT-3'; OCT-4 forward, 5'-TCTCCAGGTTGCCCTCACT-3'; reverse, 5'-GTGGAG GAAGCTGACAACAA-3'; SOX2 forward, 5'-GTCATTTG CTGTGGGTGATG-3'; reverse, 5'-AGAAAAACGAGGGA AATGGG-3'; Klf4 forward, 5'-CCCCGTGTGTTTACG GTAGT-3'; reverse, 5'-GAGTTCCCATCTCAAGGCAC-3'; GAPDH forward, 5'-ACATCCCCTCACCAATAACAAC-3'; reverse, 5'-TAGCCAAATCATACTGCTCGTC-3'.

Western blotting. For the analysis of expression of related proteins, western blot assay was performed according to a standard method, as described previously (42). The following primary antibodies were used: mouse anti-vimentin, mouse anti-E-cadherin (CST, cell signal technique); mouse antifibronectin, mouse anti-N-cadherin (BD Biosciences); mouse anti-Grb2, anti-pShc and anti-pERK1/2 (Abcam). Blotting 
membranes were stripped and re-probed with anti-tubulin antibody (Sigma) as a loading control. Nuclear extracts were prepared using the Nuclear Extraction kit (Active Motif), according to the manufacturer's instructions.

Wound healing assay. PCa cells were cultured on 6-well plates with DMEM containing $10 \%$ FBS to $90 \%$ conflucency and scratched with a sterile $10 \mu \mathrm{l}$ pipette tip to create artificial wounds. After scratching, the detached and damaged cells were carefully washed with phosphate-buffered solution (PBS) and maintained in 10\% fetal bovine serum media. Progression of migration was observed and photographed at $24 \mathrm{~h}$ after wounding. Images of the cells migrating into the wound were taken at the time points of 0,6 and $12 \mathrm{~h}$ by an inverted microscope $(\mathrm{x} 40)$.

Invasion assays. Cell invasion assays were performed using Transwell chambers consisting of $8-\mathrm{mm}$ membrane filter inserts (Corning; Corning Inc.) coated with Matrigel (BD Biosciences). Briefly, the trypsinized PCa cells were resuspended in serum-free medium and seeded in the upper chamber. Then, the lower chamber of the Transwell was filled with $1 \mathrm{ml}$ Ham's F-12 medium or T-medium supplemented with $10 \%$ FBS. After incubation for $24-48 \mathrm{~h}$ at $37^{\circ} \mathrm{C}$ in $5 \% \mathrm{CO}_{2}$, cells passing through the coated membrane to the bottom side of the inserts were fixed with $4 \%$ paraformaldehyde and stained with hematoxylin. The non-migratory cells on the upper chamber were removed with cotton swabs, and the migratory cells were stained, photographed, and quantified by counting them in 5 random high-power fields.

Colony formation assay. The cells were trypsinized as single cells and suspended in the media with $10 \%$ FBS. Indicated cells (300 cells per well) were seeded into of 6-well plate for $\sim 10$-14 days. Colonies were stained with $1 \%$ crystal violet for $10 \mathrm{~min}$ after fixation with $10 \%$ formaldehyde for $5 \mathrm{~min}$. Plating efficiency $=$ number of colonies $(\geq 50$ cells per colony $) /$ per input cells x $100 \%$. Different colony morphologies were captured under a light microscope (Olympus).

Self-renewing spheroid formation assay. Indicated cells (500 cells/well) were seeded into 6-well Ultra Low Cluster plate (Corning) and were cultured in suspension in serum-free DMEM/F12 (BioWhittaker), supplemented with 2\% B27 (Invitrogen), $20 \mathrm{ng} / \mathrm{ml}$ EGF (BD Biosciences), $20 \mathrm{ng} / \mathrm{ml} \mathrm{bFGF}$ (PeproTech), $5 \mu \mathrm{g} / \mathrm{ml}$ insulin (Sigma) and $0.4 \%$ bovine serum albumin (Sigma). After 10-12 days, the number of cell spheres (tight, spherical, non-adherent masses $>50 \mu \mathrm{m}$ in diameter) were counted, and image of the spheres were captured under inverse microscope. Sphere formation efficiency = colonies/ input cells $\times 100 \%$.

Luciferase reporter assay. Luciferase assays were carried out in 293FT cells that were co-transfected with miRNAs and luciferase reporter plasmids in 24-well plates and cultured for $48 \mathrm{~h}$ before the cells were harvested and lysed for luminescence detection. Subsequent processing and detection were performed by using the luciferase assay kit (Promega) according to the manufacturer's protocols. Renilla luciferase was activated to emit primary luminescence, and firefly lumi- nescence was used for normalization. Each test was repeated in triplicate.

Statistical analyses. All statistical analyses were carried out using SPSS 17.0 statistical software package. Means \pm SD was calculated and two-tailed Student's t-test or one-way ANOVA was performed using data analysis tools provided in the software package. In all cases, $\mathrm{P}<0.05$ was considered statistically significant.

\section{Results}

$N$-cadherin promotes invasion, migration and EMT of $\mathrm{PCa}$ cells. To investigate the biological function of $\mathrm{N}$-cadherin in PCa cells, we transducted PC-3 and DU145 PCa cells with constructed $\mathrm{pMSCV} / \mathrm{N}$-cadherin-derived retrovirus to establish $\mathrm{N}$-cadherin-overexpressing stable cell lines. As N-cadherin was not highly expressed in DU145 human prostate cell lines $(43,44)$, N-cadherin-specific RNA interference (RNAi) oligonucleotides were cloned into a retroviral transfer vector pSuper-retro-puro to establish $\mathrm{N}$-cadherin-low expressing stable cell lines only in PC-3 (Fig. 1A). Western blot analysis suggested that $\mathrm{N}$-cadherin expression is positively related with the expression of mesenchymal makers fibronectin and vimentin, but negatively related with the expression of epithelial marker E-cadherin in PC-3 and DU145 cells (Fig. 1B). On the contrary, the low expression of $\mathrm{N}$-cadherin significantly reduced the expression of fibronectin and vimentin and increased the expression of E-cadherin in PC3 cells (Fig. 1B). The result suggested that $\mathrm{N}$-cadherin expression might be involved in EMT of PCa cells. Firstly, upon knockdown of $\mathrm{N}$-cadherin in PC-3 cells, we noted that PC-3 cells underwent a marked change in morphology, from spindle like morphology to epithelial transition (Fig. 1C). Moreover, Transwell matrix penetration assay revealed that overexpression of $\mathrm{N}$-cadherin promoted, while silencing $\mathrm{N}$-cadherin strongly repressed the invasive ability compared to vector cells (Fig. 1D). In addition, wound healing assay showed that upregulation of $\mathrm{N}$-cadherin increased, while knockdown of $\mathrm{N}$-cadherin decreased healing speed of the scratch in transducted cells (Fig. 2). These data demonstrated that $\mathrm{N}$-cadherin was able to modulate the invasion and migration properties of PCa cells.

$N$-cadherin promotes colony, spheroid formation and Sox2, c-Myc, Oct4 and Klf4 expression in PCa cells. Numerous studies suggested that cancer stem cells are involved in tumor metastasis $(10,45)$. Firstly, colony formation assays was used to explore whether $\mathrm{N}$-cadherin had an effect on viability of $\mathrm{PCa}$ cells in vitro. Results showed overexpression of $\mathrm{N}$-cadherin significantly enhanced colony formation efficiency in both PC-3 and DU145 cells, while downregulation of N-cadherin markedly inhibited colony formation efficiency in PC-3 cells (Fig. 3A). As shown (Fig. 3B), the number of colonies (\% plating efficiency) was $85.7 \%$ in $\mathrm{PC}-3 / \mathrm{N}$-cadherin versus $62.8 \%$ in PC-3/vector, $63.3 \%$ in PC-3/scramble versus $38.1 \%$ in PC-3/N-cadherin-RNAi\#1 and $40.5 \%$ in PC-3/N-cadherinRNAi\#2 cells, and $77.6 \%$ in DU145 cells transfected with $\mathrm{N}$-cadherin versus $55.9 \%$ in DU145/vector. Colonies with different morphologies in vitro are classified as holoclones, meroclones and paraclones (46). Holoclones are generally 
A
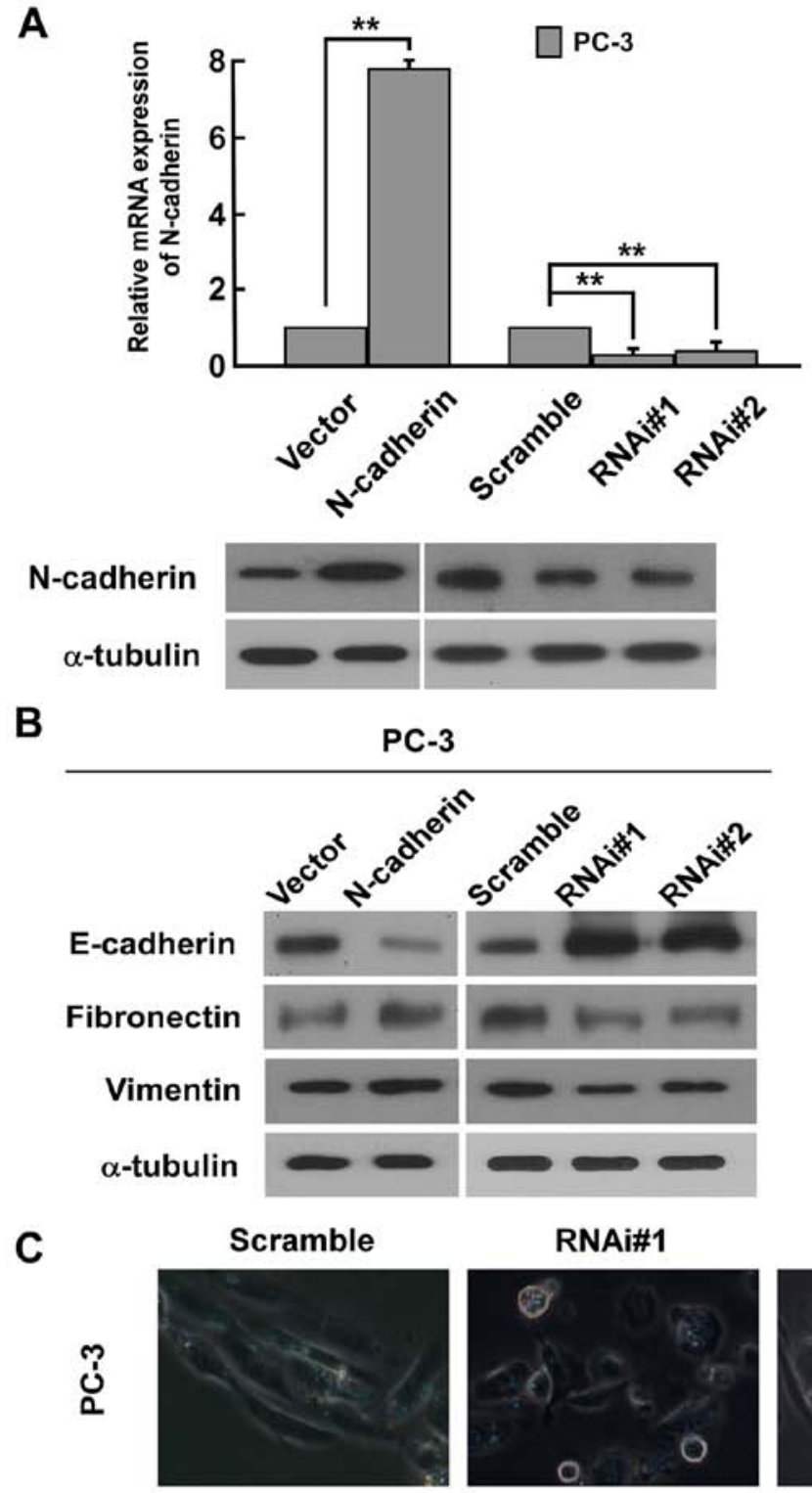

D

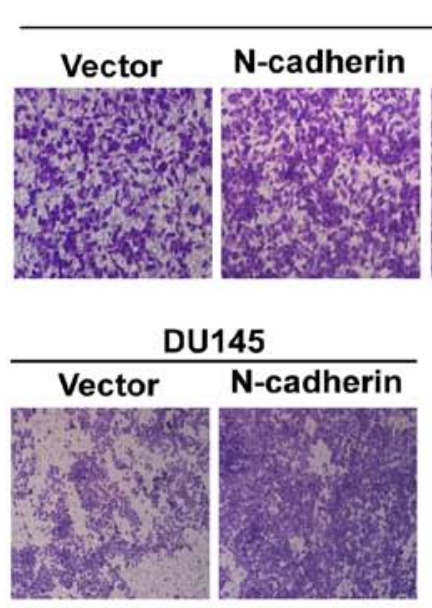

PC-3
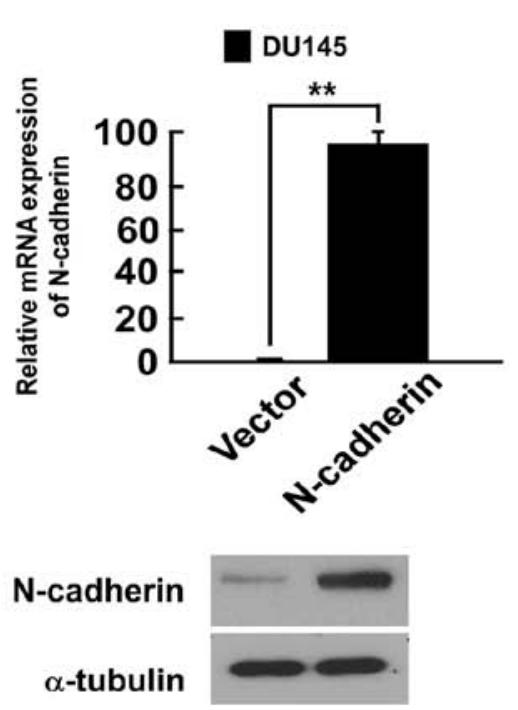

DU145

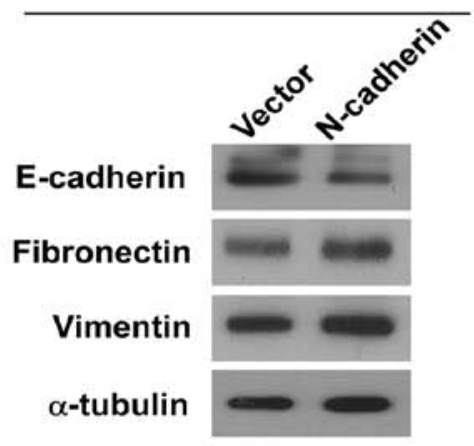

RNAi\#2
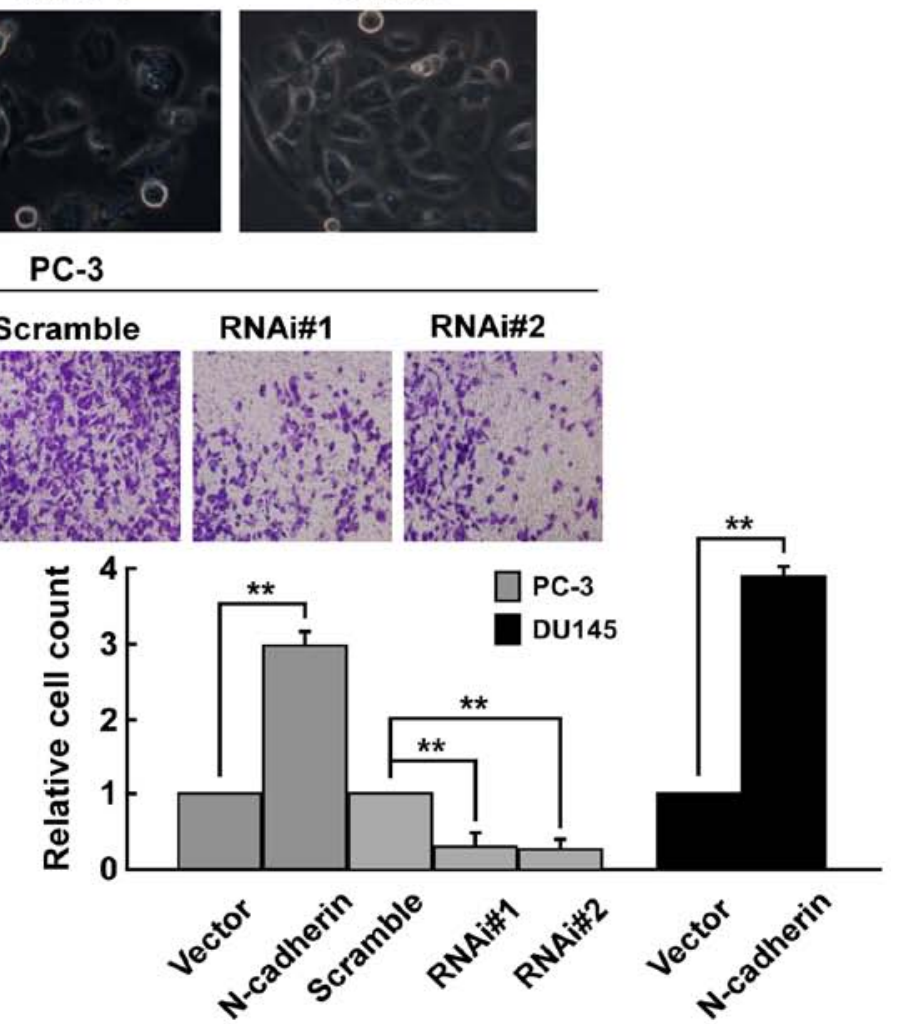

Figure 1. N-cadherin promotes invasiveness and EMT in PCa cells. (A) Expression of N-cadherin was detected by real-time PCR and western blotting $\left({ }^{* *} \mathrm{p}<0.01\right)$. (B) $\mathrm{N}$-cadherin expression is positively related with the expression of mesenchymal makers fibronectin and vimentin, but negatively related with the expression of epithelial marker E-cadherin in PC-3 and DU145 cells. (C) Downregulation of N-cadherin converted a stick-like or long spindle-shaped mesenchymal profile to a cobblestone-like or a short spindle-shaped epithelial morphology in PC-3 cells. (D) Overexpression of N-cadherin increased invasion in PC-3 and DU145 cells, while downregulation of N-cadherin efficiently reduced invasion in PC-3 cells $\left(^{* *} \mathrm{p}<0.01\right)$. 
A

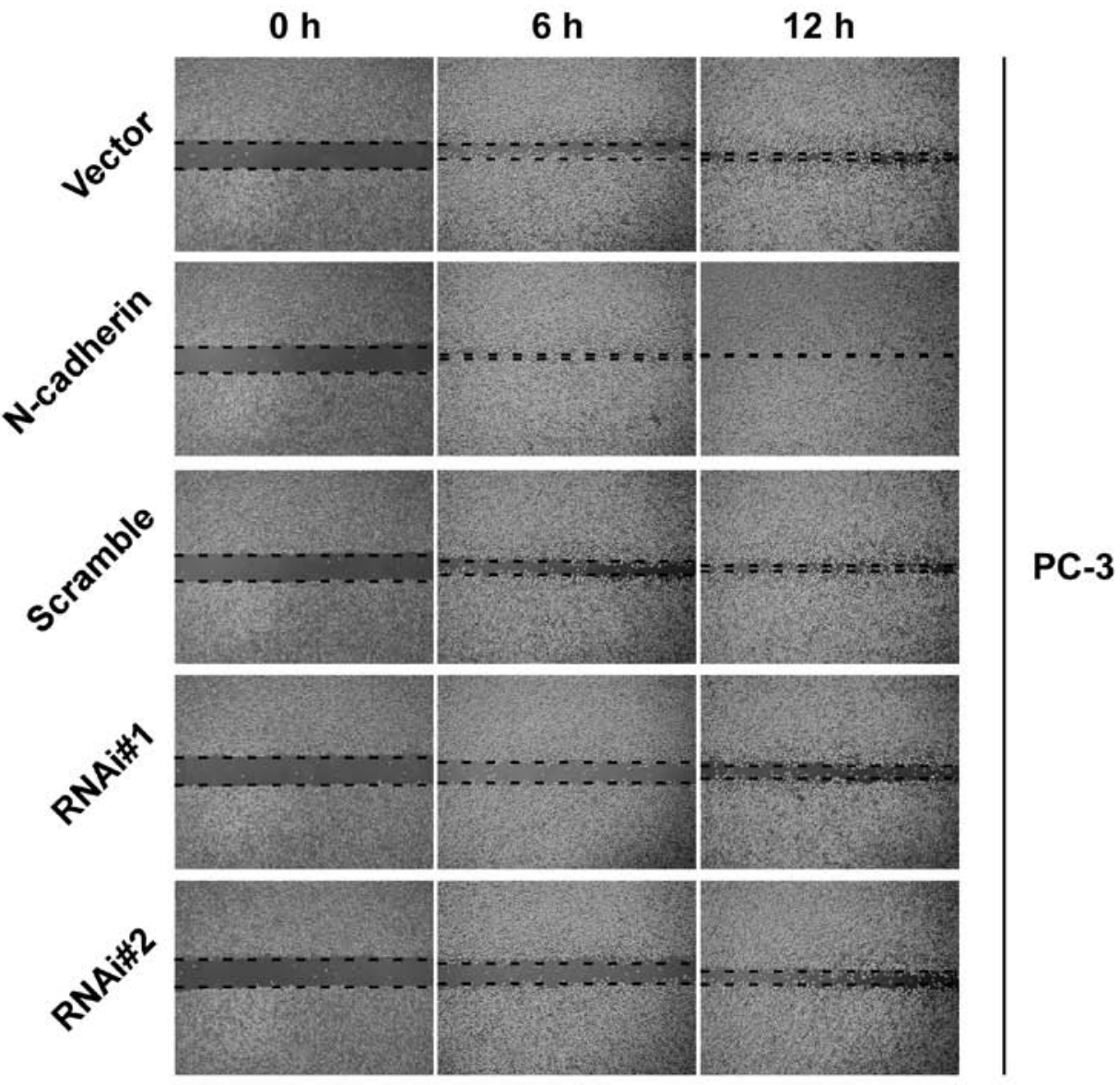

B

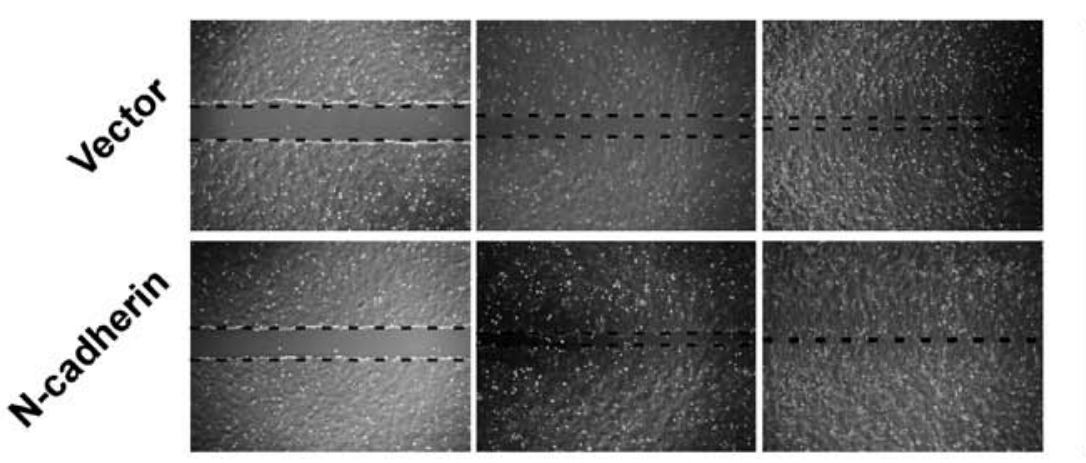

\section{DU145}

Figure 2. N-cadherin promotes the ability of wound healing in PCa cells. (A) Overexpression of N-cadherin increased, while downregulation of N-cadherin efficiently suppressed migration in PC-3 cells. (B) Overexpression of N-cadherin increased migration in DU145 cells.

more round and tightly packed; paraclones are irregular in composition and often contain more elongated or flattened cells; and meroclones are an intermediate phenotype (Fig. 3C). We did not find typical holoclones in PC-3 and DU145 cells. The proportion of meroclones was $87.6 \%$ in $\mathrm{PC}-3 / \mathrm{N}$-cadherin, $77.2 \%$ in $\mathrm{PC}-3 /$ vector and $78.1 \%$ in $\mathrm{PC}-3 /$ scramble, $52.2 \%$ in $\mathrm{PC}-3 / \mathrm{N}$-cadherin-RNAi\#1 and $55.4 \%$ in PC-3/N-cadherin-RNAi\#2 cells, and $84.7 \%$ in DU145 cells of N-cadherin overexpression versus $75.3 \%$ in DU145/ vector. Overexpression of $\mathrm{N}$-cadherin significantly increased the proportion of meroclones of PCa cells ( $p<0.01$, Fig. 3D). Moreover, sphere formation assays suggested that upregulating $\mathrm{N}$-cadherin enhanced the number and size of tumor spheroids in both PC-3 and DU145 cells, while downregu- lating $\mathrm{N}$-cadherin inhibited the number and size of tumor spheroids in PC-3 cells (Fig. 4A). The spheroid formation efficiency was $7.1 \%$ in $\mathrm{PC}-3 / \mathrm{N}$-cadherin versus $4.2 \%$ in $\mathrm{PC}-3 /$ vector, $4.4 \%$ in $\mathrm{PC}-3 /$ scramble versus $2.0 \%$ in $\mathrm{PC}-3 / \mathrm{N}-$ cadherin-RNAi\#1 cells and 2.2\% PC-3/N-cadherin-RNAi\#2, and $6.7 \%$ in DU145 cells overexpressing $\mathrm{N}$-cadherin versus $4.0 \%$ in DU145/vector (Fig. 4B). Real-time PCR was performed to examine the mRNA level of pluripotency-associated markers including Sox2, c-Myc, Oct4 and Klf4. The result suggested that CSC markers were significantly higher expressed in $\mathrm{N}$-cadherin-transduced cells than control group and significantly lower expressed in N-cadherin-RNAi cells (Fig. 4C). Thus, our results suggested that overexpression of $\mathrm{N}$-cadherin promotes prostate CSC-like traits. 

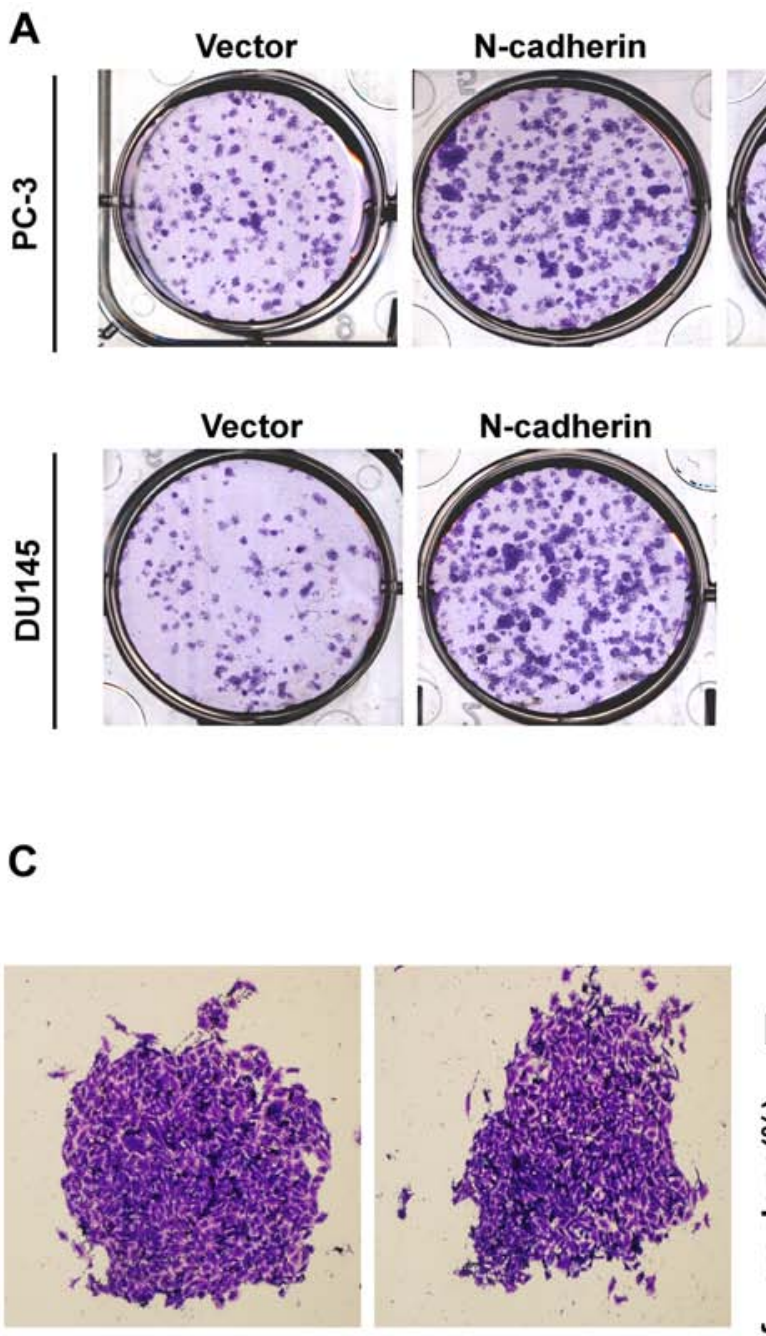

B
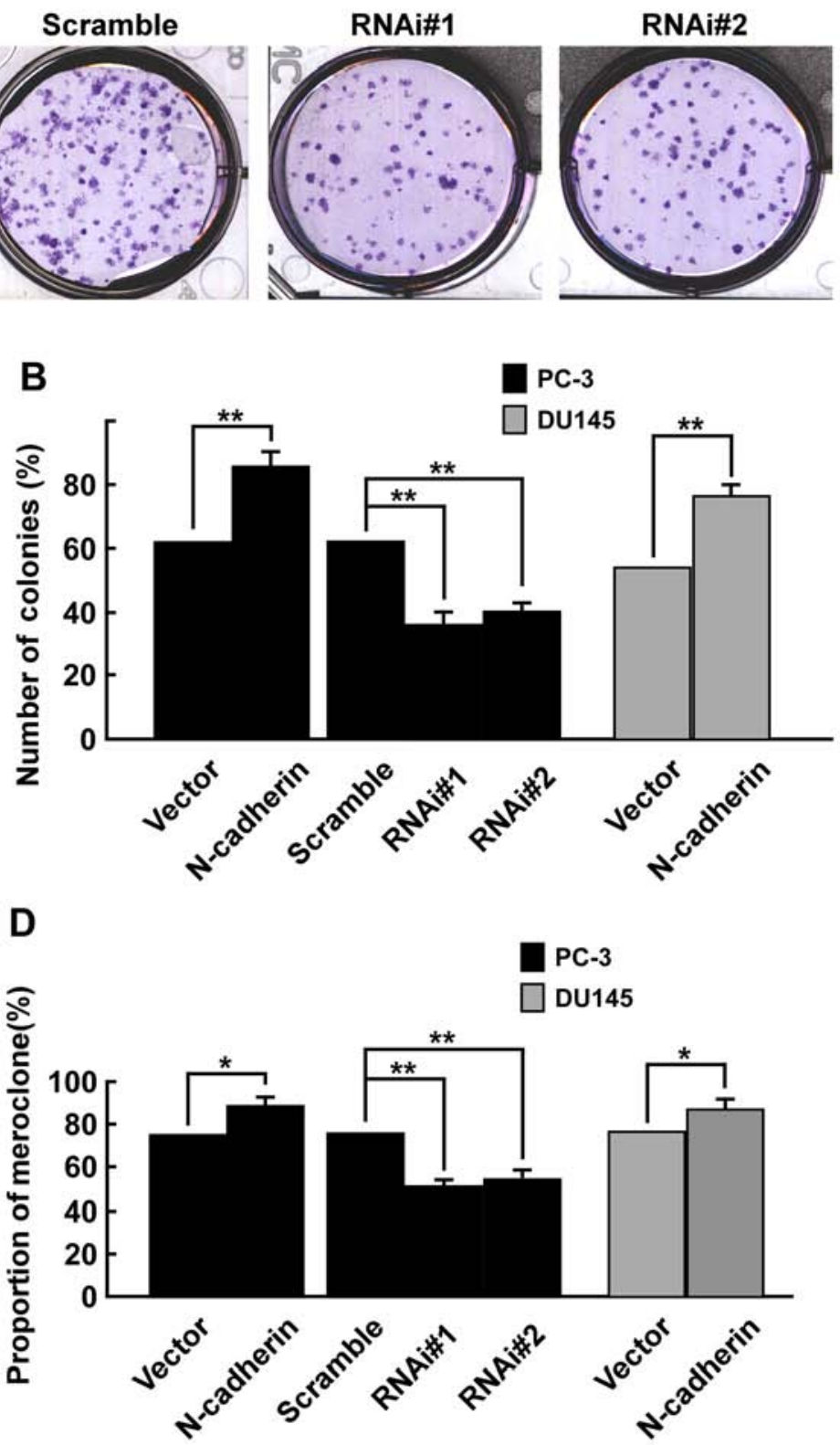

Figure 3. N-cadherin promoted the ability of colony formation in PCa cells. (A) Colony formation in PC-3 and DU145 cells. (B) Overexpression of N-cadherin increased, while downregulation of $\mathrm{N}$-cadherin significantly repressed the number of colonies formed $\left({ }^{* *} \mathrm{p}<0.01\right)$. (C) Meroclones and paraclones were observed. (D) Overexpression of $\mathrm{N}$-cadherin increased, while downregulation of $\mathrm{N}$-cadherin significantly repressed the proportion of meroclones $\left({ }^{*} \mathrm{p}<0.05\right.$; $\left.{ }^{* *} \mathrm{p}<0.01\right)$.

$N$-cadherin promotes EMT and CSC-like traits of PCa cells via ErbB signaling pathway. To understanding the underlying mechanism of $\mathrm{N}$-cadherin in regulation of EMT and stemness of PCa cells, we performed microarray analysis on PC-3/vector and PC-3/N-cadherin cells. As shown in Fig. 5, the microarray data showed a comprehensive activation of ErbB in PC-3/N-cadherin cells compared to PC-3/vector cells, which indicated that $\mathrm{N}$-cadherin might achieve its function via ErbB signaling. To further confirm the data, downstream ERBB signaling component Grb2 and phosphorylation of components Shc and ERK were examined by western blot analysis. We found that overexpression of $\mathrm{N}$-cadherin enhanced the expression of Grb2, pShc and pERK1/2 (Fig. 6A).

In order to explore whether the stem cell-like phenotype in PCa cells is associated with ErbB signaling activation, we also analyzed the impact of blocking ErbB signaling on the stem cell population capability of N-cadherin transduced PC-3 and DU145 cell lines. We used lapatinib, a potent ATP-competitive inhibitor, to inhibit both EGFR and HER2 (100 nM). Western blot analysis showed that lapatinib successfully reduced downstream Grb2, pShc and pERK1/2 in PC-3 and DU145 cells (Fig. 6B). Furthermore, western blot analysis showed that fibronectin and vimentin expression were suppressed in the lapatinib treated PCa cells, while expression of E-cadherin was increased (Fig. 6C). Colony formation assays suggested that the number of colonies were inhibited in the treatment cells compared with N-cadherin-transduced cells (Fig. 6D). Real-time PCR analysis showed that the mRNA expression level of 'stemness' factors c-Myc, Oct4, Klf4, and Sox 2 were downregulated in the lapatinib-treated cells compared with 
A
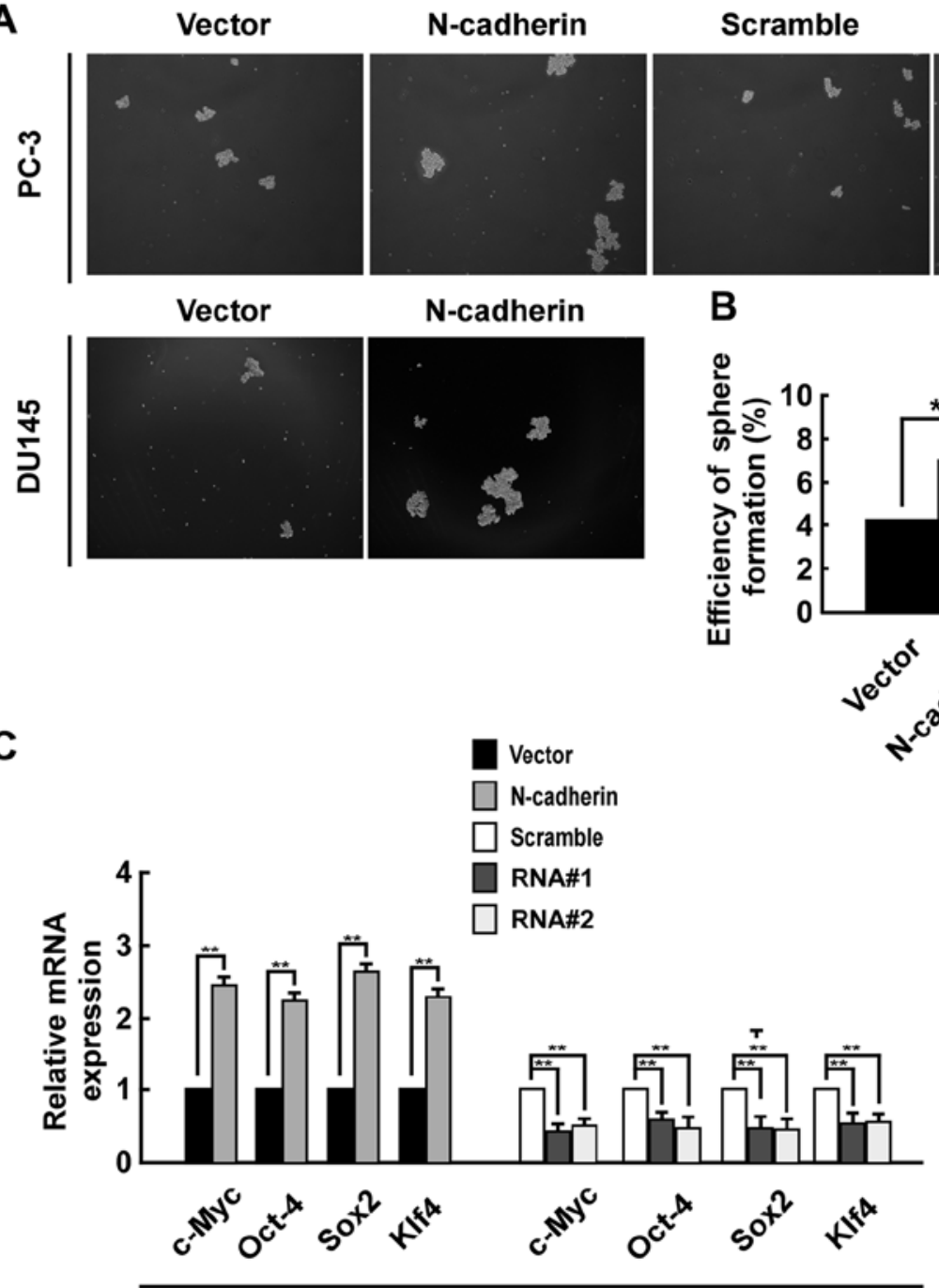

PC-3

Scramble

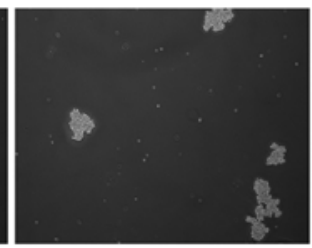

$\mathrm{N}$-cadherin

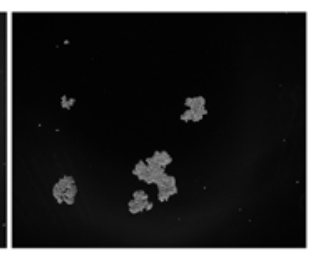

B

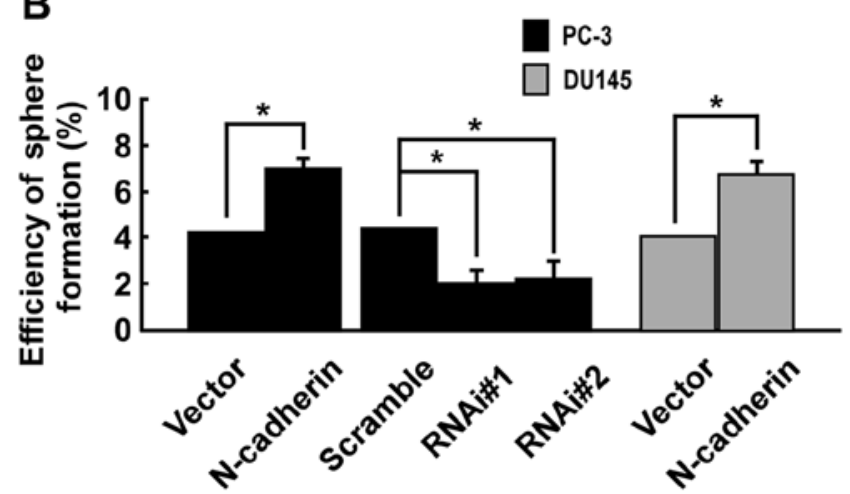

Vector

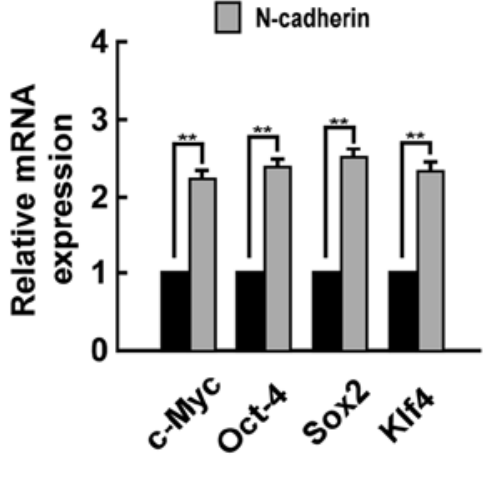

DU145

Figure 4. N-cadherin enhanced tumor sphere formation and stemness factor expression. (A and B) Overexpression of N-cadherin increased, while downregulation of $\mathrm{N}$-cadherin efficiently suppressed spheroid formation $\left({ }^{*} \mathrm{p}<0.05 ;{ }^{* *} \mathrm{p}<0.01\right)$. (C) Overexpression of $\mathrm{N}$-cadherin increased, while downregulation of $\mathrm{N}$-cadherin significantly reduced the mRNA expression levels of C-Myc, Oct4, Sox 2 and Klf4 (** $\mathrm{p}<0.01)$.

Sig pathway of DE gene

Axon guidance - Homo sapiens (human)

ErbB signaling pathway - Homo sapiens (human) Complement and coagulation cascades - Homo sapiens (human)

Calcium signaling pathway - Homo sapiens (human)

ECM-receptor interaction - Homo sapiens (human)

Focal adhesion - Homo sapiens (human)

Epithelial cell signaling in Helicobacter pylori infection - Homo sapiens (human)

Proteoglycans in cancer - Homo sapiens (human)

Gastric acid secretion - Homo sapiens (human)

Cholinergic synapse - Homo sapiens (human)

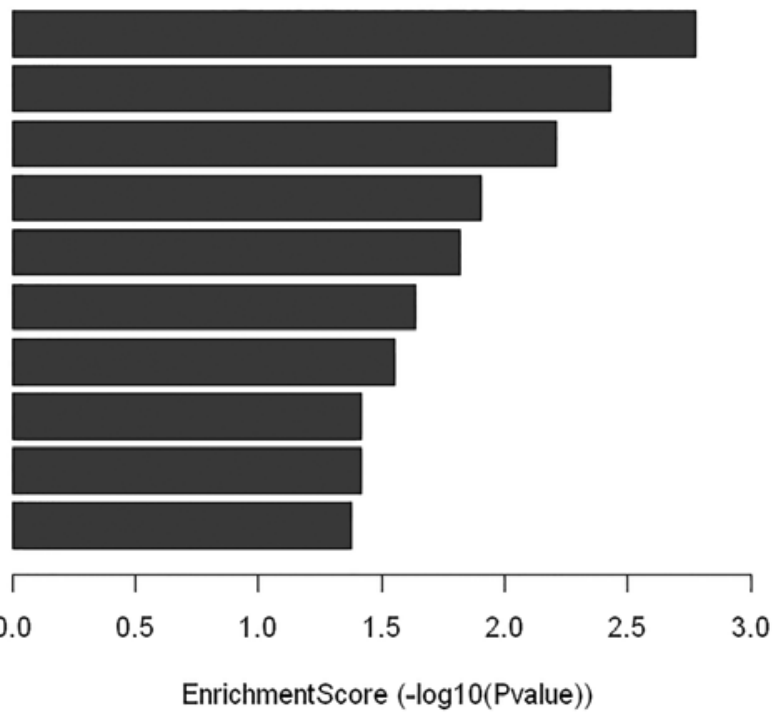

Figure 5. Expression profiling of signaling pathway in N-cadherin overexpressing PC-3 cells. 
A

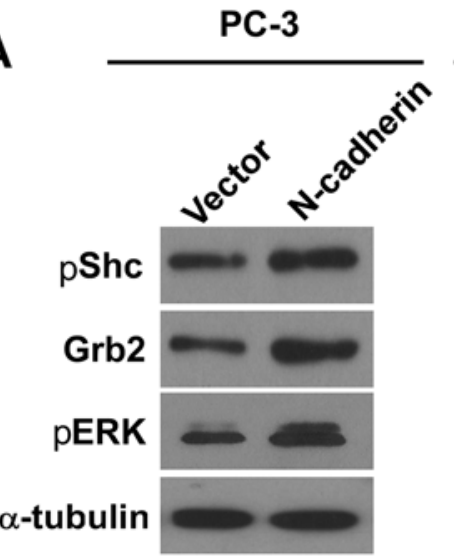

C

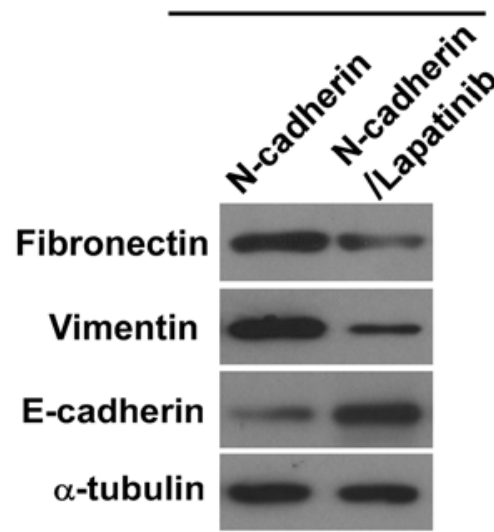

DU145

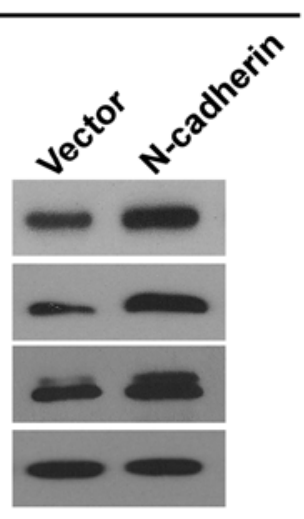

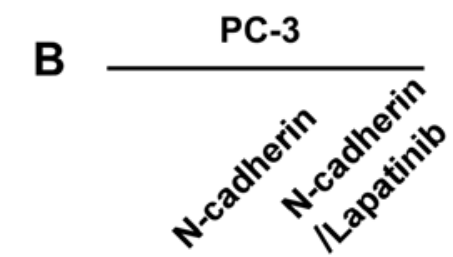
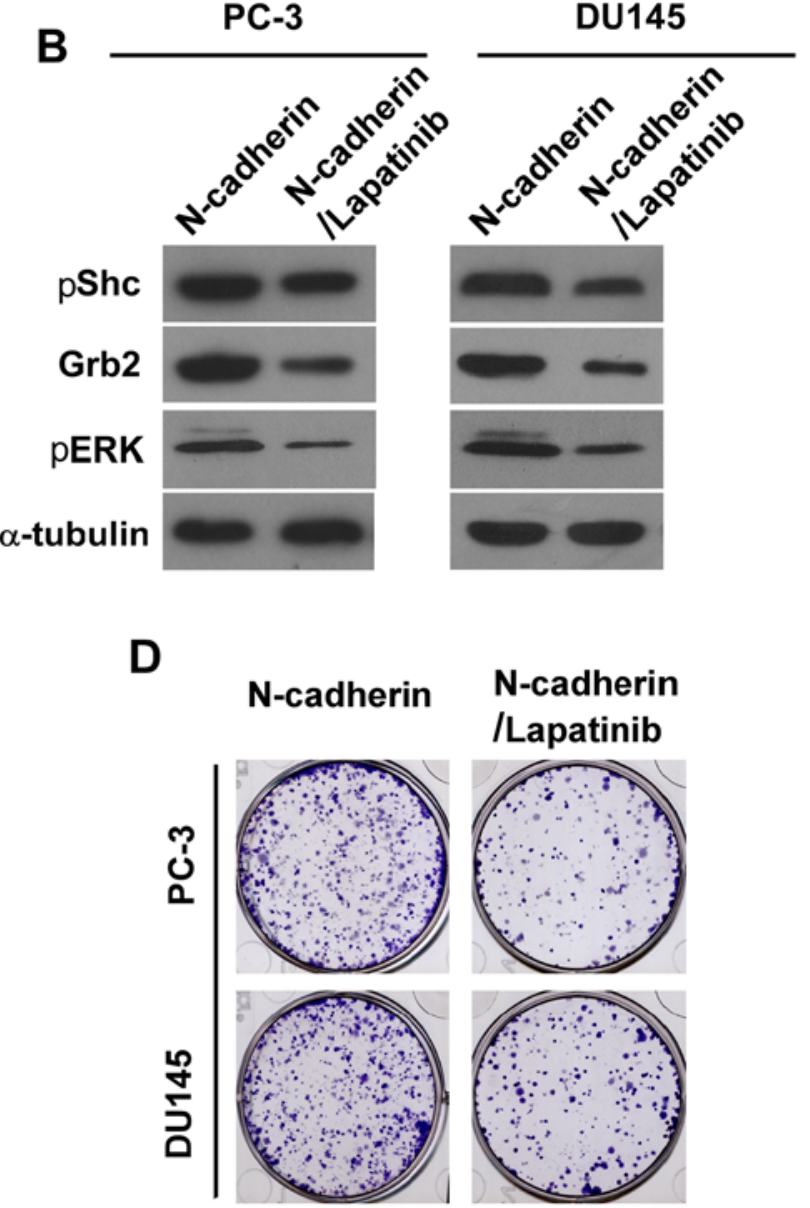

E
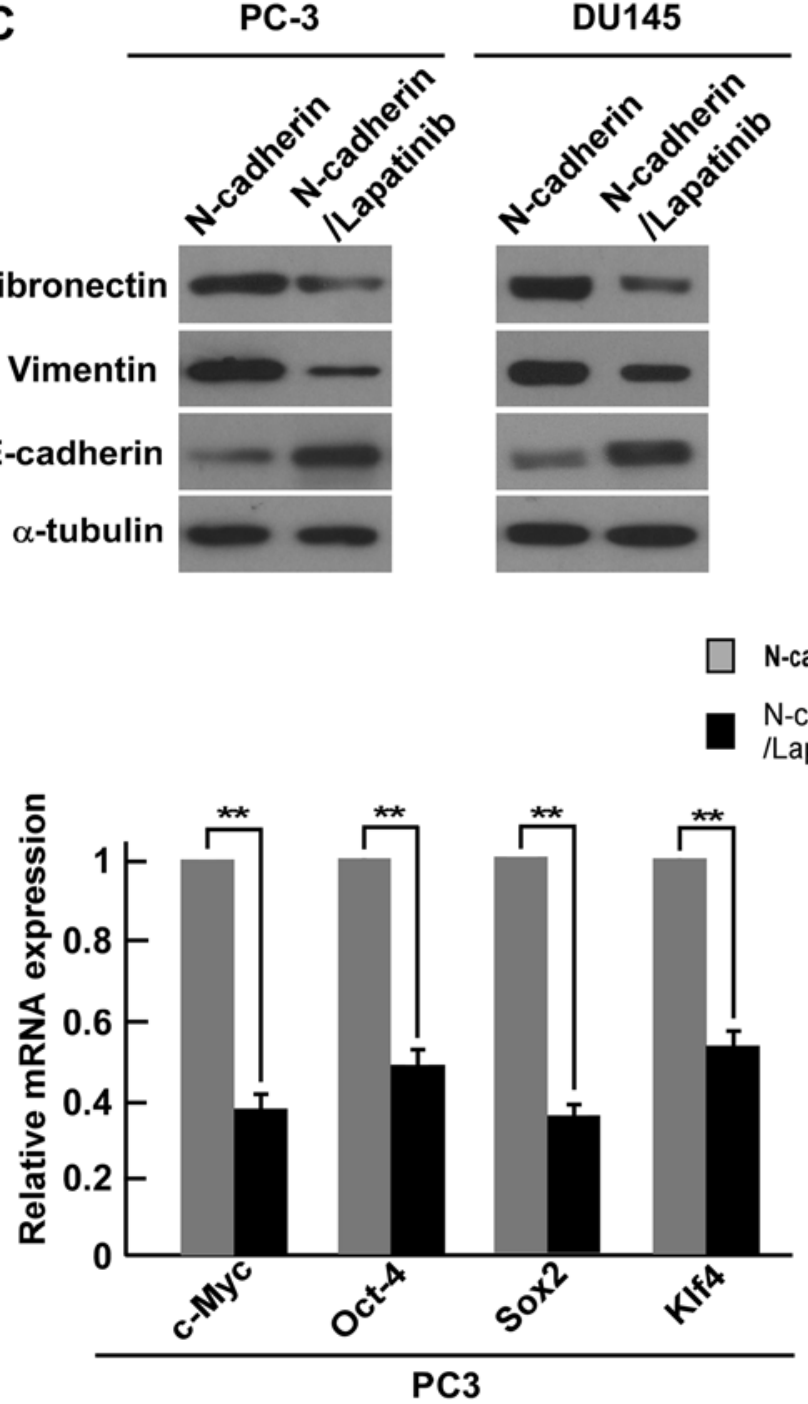

-cadherin

$\mathrm{N}$-cadherin

/Lapatinib

Figure 6. N-cadherin promotes EMT and CSC-like traits of PCa cells via ErbB signaling pathway. (A) Overexpression of N-cadherin enhanced the expression of downstream ErbB signaling component Grb2, pShc and pERK. (B) Lapatinib suppressed Grb2, pShc and pERK in PC-3 and DU145 cells. (C) Lapatinib decreased the expression of mesenchymal makers fibronectin and vimentin, and increased the expression of epithelial marker E-cadherin. (D) Lapatinib successfully inhibited the ability of colony formation in PCa cells. (E) Lapatinib repressed the mRNA expression levels of C-Myc, Oct4, Sox2 and Klf4 ( $\left.{ }^{* *} \mathrm{p}<0.01\right)$.

N-cadherin-transduced cells (Fig. 6E). All the above data revealed that $\mathrm{N}$-cadherin regulates EMT and CSC-like traits of PCa cells via ErbB signaling pathway.
$N$-cadherin does not mediate the function of miR-145 in PC-3 cells. Analysis using the publicly available algorithms (e.g., TargetScan, miRANDA) indicated that the N-cadherin- 
A

\section{Luc-N-cadherin-3'UTR-wt $\operatorname{miR}-145$}

C

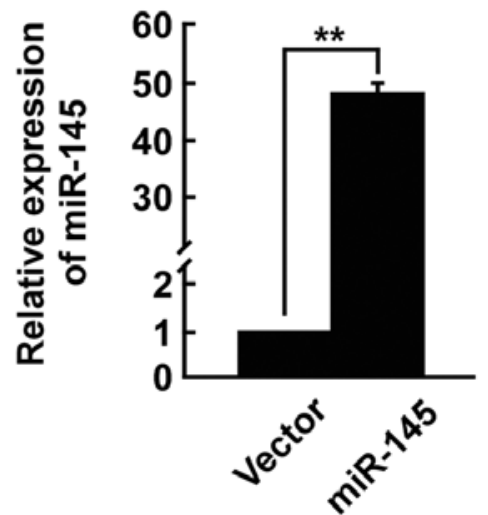

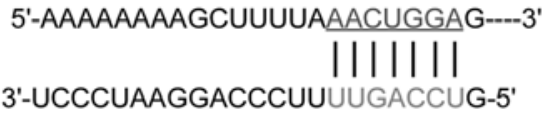

D

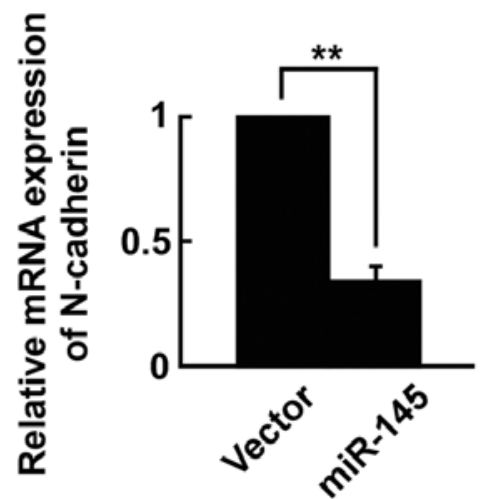

$B$

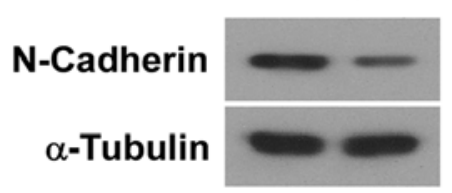

E

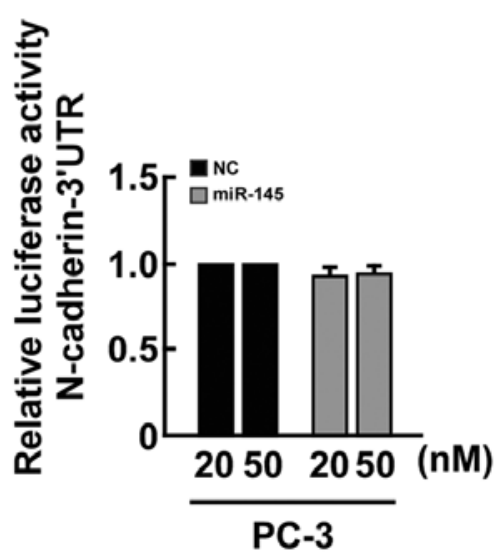

Figure 7. N-cadherin is not an authentic target of miRNA-145 in PCa cells. (A) Wild-type 3'-UTR sequence of N-cadherin was cloned into luciferase plasmids (Luc-N-cadherin-3'-UTR-wt). Solid lines indicate binding sites. (B) Expression level of the N-cadherin was detected in PC-3 cells infected with miR-145 mimics. (C) miR-145 expression was detected by real-time PCR. (D) mRNA level of N-cadherin was detected by real-time PCR ("** $<$ 0.01). (E) Luciferase assay of PC-3 cells transfected with pGL 3-N-cadherin-3'-UTR reporter with miR-145 mimic of increasing amounts (20 and $50 \mathrm{nM}$ ).

3'-UTR region is the theoretical conserved target of miR-145 (Fig. 7A). The expression level of the N-cadherin mRNA and protein was significantly decreased in miRNA-145-transfected cells (Fig. 7B-D). However, upon transfection with miR-145, we did not find strong reduction in luciferase activity from pGL3-N-cadherin-3'-UTR (Fig. 7E). Our results indicated that miR-145 did not directly target N-cadherin in PC-3 cells.

\section{Discussion}

In this study, we present a pivotal finding that overexpression of $\mathrm{N}$-cadherin promoted, while knockdown of $\mathrm{N}$-cadherin repressed EMT and stem cell-like property in PCa. Microarray analysis and further test mechanistically demonstrated that $\mathrm{N}$-cadherin achieve EMT and stemness promoting function by activating the ErbB signaling. These findings provide strong evidence that, for the first time, elevated $\mathrm{N}$-cadherin promotes EMT, stemness and metastatic ability via ErbB signaling pathway in PCa cells, which further supported that $\mathrm{N}$-cadherin could be a therapeutic target in PCa.

$\mathrm{N}$-cadherin, a mesenchymal cadherin associated with epithelial-to-mesenchymal transition, has been widely studied in various tumor types. Hazan and colleagues reported that $\mathrm{N}$-cadherin promotes adhesion between invasive breast cancer cells and the stroma (47) and overexpression of N-cadherin correlates with invasiveness in breast carcinoma (48). In PCa, $\mathrm{N}$-cadherin has also been demonstrated to be elevated and associated with poor prognosis $(13,49)$. An important finding by Tanaka and colleagues demonstrated that monoclonal antibody targeting of $\mathrm{N}$-cadherin could inhibit $\mathrm{PCa}$ growth, metastasis and castration resistance (17). Here, we found that increasing $\mathrm{N}$-cadherin enhanced, while silencing $\mathrm{N}$-cadherin impaired the invasion and migration of PCa cells. Western blot analysis showed that overexpression of $\mathrm{N}$-cadhein enhanced the expression of mesenchymal cell makers, fibronectin and vimentin, and decreased the expression of epithelial cell markers, E-cadherin, and downexpression of $\mathrm{N}$-cadherin inhibited the expression of fibronectin and vimentin, and increased the expression of E-cadherin. Moreover, upregulation of $\mathrm{N}$-cadherin also enhanced the stem cell-like property of PCa cells as indicated by higher tumor spheroids and colony formation efficiency and increased the expression of stem cell property-associated factors, including Sox2, c-Myc, Oct4 and $\mathrm{Klf} 4$, and vice versa. All together, the above presented the pivotal role of $\mathrm{N}$-cadherin in promoting metastasis in $\mathrm{PCa}$.

Although a recent study showed that $\mathrm{N}$-cadherin-driven EMT and stemness properties depend on FGFR activation, ERK activity, matrix metalloproteinase 9 production and on selective inhibition of the AKT3 isoform in many solid tumors $(14,16,50)$, our results showed that the mechanism via which $\mathrm{N}$-cadherin regulates invasion, migration, EMT and stem celllike property in $\mathrm{PCa}$ is different from that in breast cancer. The present findings indicated that $\mathrm{N}$-cadherin-driven EMT and stemness properties at least partially depend on ErbB signaling in PCa cells. Furthermore, accumulating evidence also shows that ErbB signaling pathway is associated with poor prognosis in various cancers. In glioma, ErbB1, known as EGFR, extracellular missense mutations as a novel mechanism for oncogenic EGFR activation may help identify patients 
who can benefit from EGFR kinase inhibitors for treatment of glioblastoma (22); in lung cancer, especially non-small cell lung carcinoma (NSCLC), it has been reported that EGFR amplication is universal and EGFR mutations in lung carcinomas make the disease more responsive to treatment with tyrosine kinase inhibitors (23-25); in breast cancer, EGFR was regarded as a predictor of early recurrence and death (27), and ErbB2, also known as HER2, serves as an important prognosis maker and therapy target for breast cancer (29). Further studies have demonstrated that HER2 could induce EMT in both mammary epithelial cells (32) and breast cancer cells $(33,34)$. Furthermore, some evidence reported that glioblastoma cancer stem-like cell resistance to EGFR-targeted inhibition was mediated by activation of multiple ERBB family receptors (35). In head and neck squamous cell carcinoma, EGFR kinase promotes acquisition of stem cell-like properties (36). Therefore, all the above-mentioned evidence indicated that ErbB signaling pathway plays an important role in metastasis of cancer.

For most PCa patients who were identified in the early stages the initial therapies mostly result in significant long-term remission (51). However, for advanced metastatic cases these treatments, such as prostatectomy, radiation and cryotherapy, show little benefit and without effective control the patients eventually die of the disease. Although androgen deprivation and chemotherapy are currently effective treatments for these patients, development of hormone ablation resistance is inevitable (52), which is termed castration-resistant PCa. Consequently, improved understanding of the mechanisms underlying mCRPC progression has contributed to the recognition of multiple molecular targets and advances in the therapeutic landscape. Recent study indicated that $\mathrm{N}$-cadherin is crucial in PCa progression not only to metastasis, but also to castration resistance (17). Our results showed that $\mathrm{N}$-cadherin promoted EMT and stemness of CSCs of PCa cells by upregulating ErbB signaling. Because EMT and CSCs play crucial roles during the development of castration-resistance in $\mathrm{PCa}$ (12), one of the important mechanism by which $\mathrm{N}$-cadherin increased castration resistance of metastatic PCa cells may promote EMT and stemness of CSCs of PCa cells by upregulating ErbB signaling. Therefore, understanding the inhibition of this signaling pathway may be useful to develop new therapies for metastatic PCa.

A wide range of studies have demonstrated that many microRNAs (miRNAs), as crucial post-transcriptional regulators repressing the expression of their target genes, play a pivotal role in solid tumor metastasis via regulating migration, invasion and EMT of cancer cells and the properties of CSCs (53-58). Our previous studies found that miR-145 played an important role in inhibiting migration, invasion, EMT and stemness properties of PCa cells via different targets $(40,59,60)$. Furthermore, recent study showed that $\mathrm{N}$-cadherin was a direct target of miR-145 and promoted the invasionmetastasis cascade in gastric cancer (61). Moreover, our present results showed that $\mathrm{N}$-cadherin promoted EMT and stemness properties of PCa cells. Therefore, we can suppose that $\mathrm{N}$-cadherin mediates the function of miR-145 in regulating EMT and stemness properties in PCa cells. However, we used dual-luciferase reporter gene assay to check the relationship between miR-145 and N-cadherin, and found miR-145 did not targets $\mathrm{N}$-cadherin in PC-3 cell. This difference may be due to the using of different tumor models. It will be of great interest to investigate the reasons why miR-145 is off-target for $\mathrm{N}$-cadherin in PCa cells.

In conclusion, this study demonstrated that $\mathrm{N}$-cadherin promotes invasion, migration, EMT and stemness of PCa cells, which suggest a pivotal role of $\mathrm{N}$-cadherin in metastasis and castration resistance of PCa cells. Importantly, these findings exploit interesting and realistic avenues for cancer therapies using $\mathrm{N}$-cadherin antagonists.

\section{Acknowledgements}

This study was supported by grants from the National Natural Science Foundation of China (nos. 81272938 and 81472505).

\section{References}

1. Carlin BI and Andriole GL: The natural history, skeletal complications, and management of bone metastases in patients with prostate carcinoma. Cancer 88 (Suppl): 2989-2994, 2000.

2. Karantanos T, Corn PG and Thompson TC: Prostate cancer progression after androgen deprivation therapy: Mechanisms of castrate resistance and novel therapeutic approaches. Oncogene 32: 5501-5511, 2013.

3. Friedlander TW, Ngo VT, Dong H, Premasekharan G, Weinberg V, Doty S, Zhao Q, Gilbert EG, Ryan CJ, Chen WT, et al: Detection and characterization of invasive circulating tumor cells derived from men with metastatic castration-resistant prostate cancer. Int J Cancer 134: 2284-2293, 2014

4. Berx G, Raspé E, Christofori G, Thiery JP and Sleeman JP: Pre-EMTing metastasis? Recapitulation of morphogenetic processes in cancer. Clin Exp Metastasis 24: 587-597, 2007.

5. Al-Hajj M, Wicha MS, Benito-Hernandez A, Morrison SJ and Clarke MF: Prospective identification of tumorigenic breast cancer cells. Proc Natl Acad Sci USA 100: 3983-3988, 2003.

6. Singh SK, Hawkins C, Clarke ID, Squire JA, Bayani J, Hide T, Henkelman RM, Cusimano MD and Dirks PB: Identification of human brain tumour initiating cells. Nature 432: 396-401, 2004.

7. Ricci-Vitiani L, Lombardi DG, Pilozzi E, Biffoni M, Todaro M, Peschle $\mathrm{C}$ and De Maria R: Identification and expansion of human colon-cancer-initiating cells. Nature 445: 111-115, 2007.

8. Nagata T, Sakakura C, Komiyama S, Miyashita A, Nishio M, Murayama Y, Komatsu S, Shiozaki A, Kuriu Y, Ikoma H, et al: Expression of cancer stem cell markers CD133 and CD44 in locoregional recurrence of rectal cancer. Anticancer Res 31: 495-500, 2011

9. Merlos-Suárez A, Barriga FM, Jung P, Iglesias M, Céspedes MV, Rossell D, Sevillano M, Hernando-Momblona X, da Silva-Diz V, Muñoz P, et al: The intestinal stem cell signature identifies colorectal cancer stem cells and predicts disease relapse. Cell Stem Cell 8: 511-524, 2011.

10. Pirozzi G, Tirino V, Camerlingo R, Franco R, La Rocca A, Liguori E, Martucci N, Paino F, Normanno N and Rocco G: Epithelial to mesenchymal transition by TGF $\beta-1$ induction increases stemness characteristics in primary non small cell lung cancer cell line. PLoS One 6: e21548, 2011.

11. Ribeiro AS and Paredes J: P-cadherin linking breast cancer stem cells and invasion: A promising marker to identify an 'intermediate/metastable' EMT state. Front Oncol 4: 371, 2014.

12. Li P, Yang R and Gao WQ: Contributions of epithelial-mesenchymal transition and cancer stem cells to the development of castration resistance of prostate cancer. Mol Cancer 13: 55, 2014.

13. Jennbacken K, Tesan T, Wang W, Gustavsson H, Damber JE and Welén $\mathrm{K}$ : N-cadherin increases after androgen deprivation and is associated with metastasis in prostate cancer. Endocr Relat Cancer 17: 469-479, 2010.

14. Hulit J, Suyama K, Chung S, Keren R, Agiostratidou G, Shan W, Dong X, Williams TM, Lisanti MP, Knudsen K, et al: N-cadherin signaling potentiates mammary tumor metastasis via enhanced extracellular signal-regulated kinase activation. Cancer Res 67: 3106-3116, 2007 
15. Hui L, Zhang S, Dong X, Tian D, Cui Z and Qiu X: Prognostic significance of twist and N-cadherin expression in NSCLC. PLoS One 8: e62171, 2013.

16. Qian X, Anzovino A, Kim S, Suyama K, Yao J, Hulit J, Agiostratidou G, Chandiramani N, McDaid HM, Nagi C, et al: N-cadherin/FGFR promotes metastasis through epithelial-tomesenchymal transition and stem/progenitor cell-like properties. Oncogene 33: 3411-3421, 2014.

17. Tanaka H, Kono E, Tran CP, Miyazaki H, Yamashiro J, Shimomura T, Fazli L, Wada R, Huang J, Vessella RL, et al: Monoclonal antibody targeting of $\mathrm{N}$-cadherin inhibits prostate cancer growth, metastasis and castration resistance. Nat Med 16: 1414-1420, 2010.

18. Gravdal K, Halvorsen OJ, Haukaas SA and Akslen LA: A switch from $\mathrm{E}$-cadherin to $\mathrm{N}$-cadherin expression indicates epithelial to mesenchymal transition and is of strong and independent importance for the progress of prostate cancer. Clin Cancer Res 13: 7003-7011, 2007.

19. Thompson DM and Gill GN: The EGF receptor: Structure, regulation and potential role in malignancy. Cancer Surv 4: 767-788, 1985.

20. Heimberger AB, Suki D, Yang D, Shi W and Aldape K: The natural history of EGFR and EGFRvIII in glioblastoma patients. J Transl Med 3: 38, 2005.

21. Puputti M, Tynninen O, Sihto H, Blom T, Mäenpää H, Isola J, Paetau A, Joensuu H and Nupponen NN: Amplification of KIT, PDGFRA, VEGFR2, and EGFR in gliomas. Mol Cancer Res 4 927-934, 2006.

22. Lee JC, Vivanco I, Beroukhim R, Huang JH, Feng WL, DeBiasi RM, Yoshimoto K, King JC, Nghiemphu P, Yuza Y, et al: Epidermal growth factor receptor activation in glioblastoma through novel missense mutations in the extracellular domain. PLoS Med 3: e485, 2006

23. Sharma SV, Bell DW, Settleman J and Haber DA: Epidermal growth factor receptor mutations in lung cancer. Nat Rev Cancer 7: 169-181, 2007.

24. Marchetti A, Martella C, Felicioni L, Barassi F, Salvatore S, Chella A, Camplese PP, Iarussi T, Mucilli F, Mezzetti A, et al: EGFR mutations in non-small-cell lung cancer: Analysis of a large series of cases and development of a rapid and sensitive method for diagnostic screening with potential implications on pharmacologic treatment. J Clin Oncol 23: 857-865, 2005.

25. Sholl LM, Yeap BY, Iafrate AJ, Holmes-Tisch AJ, Chou YP, Wu MT, Goan YG, Su L, Benedettini E, Yu J, et al: Lung adenocarcinoma with EGFR amplification has distinct clinicopathologic and molecular features in never-smokers. Cancer Res 69: 8341-8348, 2009.

26. Dacic S, Flanagan M, Cieply K, Ramalingam S, Luketich J, Belani C and Yousem SA: Significance of EGFR protein expression and gene amplification in non-small cell lung carcinoma. Am J Clin Pathol 125: 860-865, 2006.

27. Sainsbury JR, Farndon JR, Needham GK, Malcolm AJ and Harris AL: Epidermal-growth-factor receptor status as predictor of early recurrence of and death from breast cancer. Lancet 1 : $1398-1402,1987$

28. Bhargava R, Gerald WL, Li AR, Pan Q, Lal P, Ladanyi M and Chen B: EGFR gene amplification in breast cancer: Correlation with epidermal growth factor receptor mRNA and protein expression and HER-2 status and absence of EGFR-activating mutations. Mod Pathol 18: 1027-1033, 2005.

29. Kallioniemi OP, Kallioniemi A, Kurisu W, Thor A, Chen LC, Smith HS, Waldman FM, Pinkel D and Gray JW: ERBB2 amplification in breast cancer analyzed by fluorescence in situ hybridization. Proc Natl Acad Sci USA 89: 5321-5325, 1992.

30. Dybdal N, Leiberman G, Anderson S, McCune B, Bajamonde A, Cohen RL, Mass RD, Sanders C and Press MF: Determination of HER 2 gene amplification by fluorescence in situ hybridization and concordance with the clinical trials immunohistochemical assay in women with metastatic breast cancer evaluated for treatment with trastuzumab. Breast Cancer Res Treat 93: 3-11, 2005.

31. Zhao J, Wu R, Au A, Marquez A, Yu Y and Shi Z: Determination of HER2 gene amplification by chromogenic in situ hybridization (CISH) in archival breast carcinoma. Mod Pathol 15: 657-665, 2002.

32. Jenndahl LE, Isakson P and Baeckström D: c-erbB2-induced epithelial-mesenchymal transition in mammary epithelial cells is suppressed by cell-cell contact and initiated prior to E-cadherin downregulation. Int J Oncol 27: 439-448, 2005.
33. Lu J, Guo H, Treekitkarnmongkol W, Li P, Zhang J, Shi B, Ling C, Zhou X, Chen T, Chiao PJ, et al: 14-3-3zeta cooperates with ErbB2 to promote ductal carcinoma in situ progression to invasive breast cancer by inducing epithelial-mesenchymal transition. Cancer Cell 16: 195-207, 2009.

34. Ai M, Liang K, Lu Y, Qiu S and Fan Z: Brk/PTK6 cooperates with HER2 and Src in regulating breast cancer cell survival and epithelial-to-mesenchymal transition. Cancer Biol Ther 14 : 237-245, 2013

35. Clark PA, Iida M, Treisman DM, Kalluri H, Ezhilan S, Zorniak M, Wheeler DL and Kuo JS: Activation of multiple ERBB family receptors mediates glioblastoma cancer stem-like cell resistance to EGFR-targeted inhibition. Neoplasia 14: 420-428, 2012.

36. Abhold EL, Kiang A, Rahimy E, Kuo SZ, Wang-Rodriguez J, Lopez JP, Blair KJ, Yu MA, Haas M, Brumund KT, et al: EGFR kinase promotes acquisition of stem cell-like properties: A potential therapeutic target in head and neck squamous cell carcinoma stem cells. PLoS One 7: e32459, 2012

37. Li J, Gong L-Y, Song L-B, Jiang L-L, Liu L-P, Wu J, Yuan J, Cai J-C, He M, Wang L, et al: Oncoprotein Bmi-1 renders apoptotic resistance to glioma cells through activation of the IKK-nuclear factor- $\kappa$ B pathway. Am J Pathol 176: 699-709, 2010.

38. Chen T, Xu C, Chen J, Ding C, Xu Z, Li C and Zhao J: MicroRNA-203 inhibits cellular proliferation and invasion by targeting Bmil in non-small cell lung cancer. Oncol Lett 9: 2639-2646, 2015 .

39. Saeed AI, Sharov V, White J, Li J, Liang W, Bhagabati N, Braisted J, Klapa M, Currier T, Thiagarajan M, et al: TM4: A free, open-source system for microarray data management and analysis. Biotechniques 34: 374-378, 2003.

40. Guo W, Ren D, Chen X, Tu X, Huang S, Wang M, Song L, Zou X and Peng X: HEF1 promotes epithelial mesenchymal transition and bone invasion in prostate cancer under the regulation of microRNA-145. J Cell Biochem 114: 1606-1615, 2013.

41. Livak KJ and Schmittgen TD: Analysis of relative gene expression data using real-time quantitative PCR and the 2(-Delta Delta $\mathrm{C}(\mathrm{T})$ ) method. Methods 25: 402-408, 2001

42. Guan H, Song L, Cai J, Huang Y, Wu J, Yuan J, Li J and Li M Sphingosine kinase 1 regulates the Akt/FOXO3a/Bim pathway and contributes to apoptosis resistance in glioma cells. PLoS One 6: e19946, 2011.

43. Nalla AK, Estes N, Patel J and Rao JS: N-cadherin mediates angiogenesis by regulating monocyte chemoattractant protein-1 expression via PI3K/Akt signaling in prostate cancer cells. Exp Cell Res 317: 2512-2521, 2011.

44. Rosenberg EE, Prudnikova TY, Zabarovsky ER, Kashuba VI and Grigorieva EV: D-glucuronyl C5-epimerase cell type specifically affects angiogenesis pathway in different prostate cancer cells. Tumour Biol 35: 3237-3245, 2014.

45. Allegra A, Alonci A, Penna G, Innao V, Gerace D, Rotondo F and Musolino C: The cancer stem cell hypothesis: A guide to potential molecular targets. Cancer Invest 32: 470-495, 2014

46. Pfeiffer MJ and Schalken JA: Stem cell characteristics in prostate cancer cell lines. Eur Urol 57: 246-254, 2010.

47. Hazan RB, Kang L, Whooley BP and Borgen PI: N-cadherin promotes adhesion between invasive breast cancer cells and the stroma. Cell Adhes Commun 4: 399-411, 1997.

48. Hazan RB, Phillips GR, Qiao RF, Norton L and Aaronson SA: Exogenous expression of $\mathrm{N}$-cadherin in breast cancer cells induces cell migration, invasion, and metastasis. J Cell Biol 148: 779-790, 2000

49. Jaggi M, Nazemi T, Abrahams NA, Baker JJ, Galich A, Smith LM and Balaji KC: N-cadherin switching occurs in high Gleason grade prostate cancer. Prostate 66: 193-199, 2006.

50. Caramel J, Papadogeorgakis E, Hill L, Browne GJ, Richard G, Wierinckx A, Saldanha G, Osborne J, Hutchinson P, Tse G, et al: A switch in the expression of embryonic EMT-inducers drives the development of malignant melanoma. Cancer Cell 24: 466-480, 2013.

51. Siegel R, DeSantis C, Virgo K, Stein K, Mariotto A, Smith T, Cooper D, Gansler T, Lerro C, Fedewa S, et al: Cancer treatment and survivorship statistics, 2012. CA Cancer J Clin 62: 220-241, 2012.

52. Pagliarulo V, Bracarda S, Eisenberger MA, Mottet $\mathrm{N}$, Schröder FH, Sternberg CN and Studer UE: Contemporary role of androgen deprivation therapy for prostate cancer. Eur Urol 61: $11-25,2012$

53. Brabletz T: EMT and MET in metastasis: Where are the cancer stem cells? Cancer Cell 22: 699-701, 2012. 
54. Bracken CP, Gregory PA, Kolesnikoff N, Bert AG, Wang J, Shannon MF and Goodall GJ: A double-negative feedback loop between ZEB1-SIP1 and the microRNA-200 family regulates epithelial-mesenchymal transition. Cancer Res 68: 7846-7854, 2008.

55. Korpal M,Lee ES,Hu G and Kang Y: The miR-200 family inhibits epithelial-mesenchymal transition and cancer cell migration by direct targeting of E-cadherin transcriptional repressors ZEB1 and ZEB2. J Biol Chem 283: 14910-14914, 2008.

56. Moes M, Le Béchec A, Crespo I, Laurini C, Halavatyi A, Vetter G, Del Sol A and Friederich E: A novel network integrating a miRNA-203/SNAI1 feedback loop which regulates epithelial to mesenchymal transition. PLoS One 7: e35440, 2012.

57. Nicoloso MS, Spizzo R, Shimizu M, Rossi S and Calin GA: MicroRNAs - the micro steering wheel of tumour metastases. Nat Rev Cancer 9: 293-302, 2009.
58. Siemens H, Jackstadt R, Hünten S, Kaller M, Menssen A, Götz U and Hermeking H: miR-34 and SNAIL form a double-negative feedback loop to regulate epithelial-mesenchymal transitions. Cell Cycle 10: 4256-4271, 2011.

59. Ren D, Wang M, Guo W, Huang S, Wang Z, Zhao X, Du H, Song L and Peng X: Double-negative feedback loop between ZEB2 and miR-145 regulates epithelial-mesenchymal transition and stem cell properties in prostate cancer cells. Cell Tissue Res 358: 763-778, 2014.

60. Huang S, Guo W, Tang Y, Ren D, Zou X and Peng X: miR-143 and miR-145 inhibit stem cell characteristics of PC-3 prostate cancer cells. Oncol Rep 28: 1831-1837, 2012.

61. Gao P, Xing AY, Zhou GY, Zhang TG, Zhang JP, Gao C, Li H and Shi DB: The molecular mechanism of microRNA-145 to suppress invasion-metastasis cascade in gastric cancer. Oncogene 32: 491-501, 2013. 